\title{
DETERMINATION OF RA-226 AND RN-222 IN NATURAL DRINKING WATER IN THE PROVINCE OF GRANADA (SPAIN)
}

\author{
P. Vacas-Arquero' ${ }^{{ }^{*}}$, V.M. Expósito-Suárez ${ }^{2}$, A. Milena-Pérez ${ }^{2}$, M.A. Ferro García ${ }^{1}$
}

${ }^{1}$ Radiochemistry and Environmental Radiology Laboratory, Inorganic Chemical Department, Faculty of Sciences, University of Granada, Granada, Spain

${ }^{2}$ Centro de Investigaciones Energéticas, Medioambientales y Tecnológicas, CIEMAT Madrid, Spain

\begin{abstract}
Ra}$ is a natural radioactive isotope belonging to the natural radioactive family of ${ }^{238} \mathrm{U}$. Its radioactive decay causes the emanation of a radioactive gas, ${ }^{222} \mathrm{Rn}$. These isotopes are widely distributed in a natural and heterogeneous way in the earth's crust, so their presence in groundwater has a natural origin where their accumulation or concentration depends on several of factors such as: chemical nature of the rocks that surround the aquifer, geological characteristics of the land, the physicochemical processes that occur in the aquifer, among others, as well as an anthropogenic origin (due to mining activities or the use of fertilizers). Their determination in drinking water is important because they are a source of internal contamination with a high radiological health risk, so are the short-term high-energy alpha emitters Radon decay products. The purpose of this work is to determine the activity concentration of ${ }^{226} \mathrm{Ra}$ and its daughter ${ }^{222} \mathrm{Rn}$ in non-treated drinking water from sources distributed along the coast and Alpujarra of Granada to know their environmental implications, to determine their natural or anthropogenic origin, as well as to know if they comply the limits established by regulatory bodies (Directive 2013/51 / EURATOM and RD 314/2016) for their consumption. The Radiometric Techniques used to monitor both radionuclides have been Gamma Spectrometry with High Purity Intrinsic Germanium Detector (HPGe), and Liquid Scintillation Counter (TRI-CARB 15OO).
\end{abstract}

Keywords: Radium, Radon, Liquid Scintillation Counter, Gamma-ray Spectrometry, water, health, radioactivity

\section{INTRODUCTION}

The availability, quality, management and protection of water is, due to population growth, a matter of fundamental importance in relation to human development and the sustainability of the environment and the economy. Access to safe and reliable water is limited, and these are determining factors in maintaining human health and needs, whether due to consumption, food and energy production, industry and/or environmental protection.

The quality of the water can be compromised by the presence of radioactive isotopes, natural or artificial ones, mainly if it is water that has not been purified. In various European countries there is a growing tendency to consume natural spring waters. This, together with the fact that exposure to natural radiation sources accounts for more than $86 \%$ of the total exposure, makes radiological control of waters essential [1]. The present work focuses on the determination of an isotope of Radium, ${ }^{226} \mathrm{Ra}$, and of Radon, ${ }^{222} \mathrm{Rn}$. Both are alpha emitters, so their determination in water is very important because these are the most harmful particles for the body when they enter it, releasing all their energy in a space of a few tens of microns [2].

Radium has a total of 25 isotopes, of which 4 are natural, whose state of aggregation is solid. Of all of them, the most abundant is ${ }^{226} \mathrm{Ra}$, which has a half-life of 1600 years. This belongs to ${ }^{238} \mathrm{U}$ radioactive family and disintegrates emitting alpha particles with an energy of $4.78 \mathrm{MeV}$ in ${ }^{222} \mathrm{Rn} .{ }^{222} \mathrm{Rn}$ is the natural isotope of Radon with the highest health impact. It is the most abundant of the Radon isotopes, and has a half-life of 3.82 days.

$100 \%$ of ${ }^{222} \mathrm{Rn}$ atoms formed, disintegrate by emission of alpha particles (5.49 MeV) and become ${ }^{218}$ Po atoms; which in turn, after a series of disintegrations due to alpha and beta emissions, are transformed into heavy metal isotopes of polonium, bismuth and lead, which apart from posing a radiological risk, are chemically toxic, ending up in a stable lead isotope $(206 \mathrm{~Pb})[3]$.

${ }^{222} \mathrm{Rn}$ contributes to a large extent to the average annual dose received by both the Spanish and World populations (with $31 \%$ and $42 \%$ respectively) [1], [4] which is due, on the one hand, to the abundance of the ${ }^{238} \mathrm{U}$ in nature, and on the other, its high half-life of

*pablovacas@ugr.es 
4.5E9 years, a primordial isotope that formed at the same time as the Earth.

It is the largest natural source of alpha ionizing radiation in the gaseous state. Upon entering the body (by inhalation or ingestion), both in its disintegration and in that of its short-lived descendants, such as ${ }^{218} \mathrm{Po}$ and ${ }^{214} \mathrm{Po}$, high-energy alpha particles are emitted that can cause damage to the DNA of cells, leading to stochastic or random effects (cancer inducers) [5]. In 1988 it was declared a carcinogen by the International Agency for Research on Cancer (AIIC), an intergovernmental body belonging to the World Health Organization (WHO) and today it is the second cause of lung cancer in the world, behind tobacco, being responsible for between 3 and $14 \%$ of deaths due to this cancer according to the WHO [6]. But not only does it have a great influence on the development of lung cancer, it is also related to skin cancer [7] and leukemia [8].

The main risk of Radon resides when it is inhaled, however, it can also be found dissolved in water, this being another of the routes of entry into the human body, by ingestion of these waters, with the associated risks that the entry of alpha emitters in living things. This route poses fewer potential risks to human health than those caused by inhalation. In the case of consumption of water contaminated by ${ }^{222} \mathrm{Rn}$, the main radiological risk for people is stomach cancer [9], although it can also damage other organs and tissues since it is transported by the bloodstream to various parts of the body, emitting alpha particles and transforming into their short-period descendants, which are heavy metal isotopes of $\mathrm{Bi}, \mathrm{Po}$, and $\mathrm{Pb}$ in solid state, which are even more dangerous than radon itself because their decays give rise to high-energy alpha particles, as well as more energetic beta emission and gamma radiation.

In Spain, the Radiological control of water for human consumption is reflected in Royal Decree 140/2003, of February 7 [10]. The last modification was made on July 30, 2016 through Royal Decree 314/2016 [11], where the Radon limits in waters were set for the first time at the national level at $500 \mathrm{~Bq} / \mathrm{L}$, as a result of the transposition of the Directive 2013/51/EURATOM of the European Council, of October 22, 2013 [12], which suggests a range of activity values from $100 \mathrm{~Bq} / \mathrm{L}$ to $1000 \mathrm{~Bq} / \mathrm{L}$, among which each country selects its reference level. Due to the very short half-life of Radon, the highest levels of exhalation and emanation of ${ }^{222} \mathrm{Rn}$ (and therefore of doses) will occur in geological areas with high concentrations of ${ }^{238} \mathrm{U}$. The groundwaters with the highest content of ${ }^{226} \mathrm{Ra}$ are associated with ${ }^{238} \mathrm{U}$ reservoirs, waters that rise through faults and hot springs. Once groundwater flows into lakes, rivers, or other man-made pools of water, the Radon content is greatly reduced due to the limited amount of Radium in contact with the water, since most of the ${ }^{222} \mathrm{Rn}$ dissolved in it escapes into the atmosphere [13].

\section{MATERIALS AND METHODS}

\subsection{Samples and their location}

For the development of this work, from December 2018 to May 2019, a total of 15 untreated water for human consumption (13 fountains and 2 wells) distributed throughout the geography of Granada have been sampled, and strategically chosen, considering different scenarios such as they are the lithology of the terrain and the possible influence of exogenous anthropogenic agents.

In this way, the samples can be divided into two groups, Table:

- Coastal Zone: The lithology of this zone is predominantly composed of carbonated rocks, with low content in Uranium and therefore in Radium and Radon [14]. Its radiological interest lies in the intensive agriculture and the use of fertilizers that can seep and contaminate aquifers.

- Alpujarra Zone: In this area, metamorphic and sedimentary rocks predominate, which present a higher Uranium content than in carbonated ones [14].

Table 1. Sampling points.

\begin{tabular}{|c|c|c|c|}
\hline Sample & Zone & Elevation (m) & Litology \\
\hline P1 & Coastal & 11 & Detrital \\
P2 & Coastal & 11 & Detrital \\
F1 & Coastal & 275 & Metamorphic \\
F2 & Coastal & 30 & Metamorphic \\
F3 & Alpujarra & 1500 & Metamorphic \\
F4 & Alpujarra & 1275 & Metamorphic \\
F5 & Alpujarra & 1319 & Metamorphic \\
F6 & Alpujarra & 693 & Metamorphic \\
F7 & Coastal & 105 & Carbonated \\
F8 & Coastal & 6 & Carbonated \\
F9 & Alpujarra & 1022 & Carbonated \\
F10 & Coastal & 95 & Carbonated \\
F11 & Alpujarra & 800 & Detrital \\
F12 & Coastal & 233 & Metamorphic \\
F13 & Coastal & 445 & Carbonated \\
\hline
\end{tabular}

These waters were analyzed using Radiometric Techniques, such as Liquid Scintillation Counter, model TRI-CARB 1500 from the PACKARD brand; and a Gamma Spectrometer with a high purity Intrinsic Germanium (HPGe) detector in vertical configuration, model GR-2020 7500SL from the CANBERRA brand. As well, a chemical characterization was carried out by ion exchange chromatography and an analysis of carbonates and bicarbonates by the Wander method, as well as a characterization of the physicochemical parameters by means of the measurement "in-situ" with a multiparametric aquatic probe.

\subsection{Previous Operations}

For the determination of the concentration of Radium and Radon in the studied waters, an own methodology has been optimized and developed for the measurement with the Liquid Scintillation Counter. The results obtained are compared with those found by Gamma Spectrometry.

Previous studies were carried out to optimize the methodology for Liquid Scintillation, among which are:

- Choice of scintillating cocktail

- Water/Cocktail volume inside the counting vial

- Place of preparation of the counting vials: "in situ or in the laboratory. 


\subsection{Sampling}

The sampling procedure used, both from fountains and wells, is based on the EPA 913.0 method [15].

For the sampling of water from fountains we use a funnel with a rubber that ends in a bucket. The water from the fountain will fall into the funnel and into the bucket. By modifying the inclination of the funnel, we will control the flow of water that will fill the bucket in order to make it as linear as possible to avoid the formation of bubbles and the loss of Radon associated with them.

Wells and groundwater sampling has been done using a bucket tied to a string. The bucket is thrown into the well, filled with water, and allowed to submerge slowly to access deeper water. Once the desired depth is reached, the cube is slowly picked up and the desired portion is taken from it.
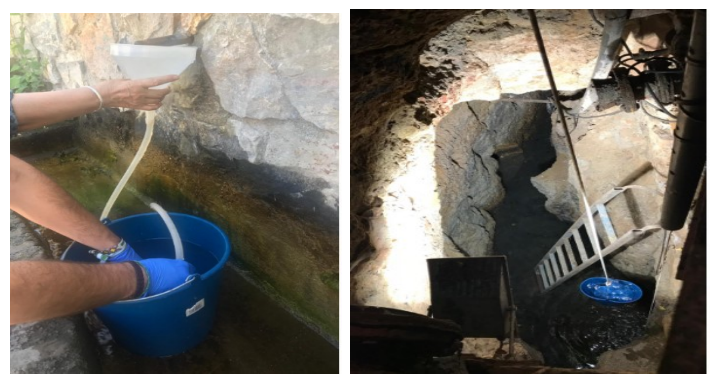

Figure 1. Sampling

\section{EXPERIMENTAL}

\subsection{Sample preparation}

For both techniques, samples will be prepared "in situ".

For liquid scintillation, borosilicate counting vials (with low ${ }^{40} \mathrm{~K}$ content) will be used. $10 \mathrm{~mL}$ of sample and $10 \mathrm{~mL}$ of "Mineral Oil" (PerkinElmer) scintillator will be introduced into them with an automatic pipette.

In the case of gamma spectrometry, the container used will be a $60 \mathrm{~mL}$ duchess of HDPE. These will be completely filled, avoiding air bubbles inside, and will be hermetically sealed.

\subsection{Liquid Scintillation Counter}

The Liquid Scintillation Counter (LSC) used is the TRI-CARB 1500 model, from the PACKARD brand. This technique is based on the ability of certain liquid chemical species, scintillating substances, to emit light when crossed by ionizing radiation present in a sample in a liquid state and to which it is added. Subsequently, the light photons generated can be detected and measured instrumentally after their conversion into electrical impulses, using photomultiplier tubes. There is a proportionality between the activity concentration of the sample and the final electrical impulse recorded.

For both energy and equipment efficiency calibration, a ${ }^{222} \mathrm{Rn}$ standard has been prepared from a certified ${ }^{226} \mathrm{Ra}$ standard supplied by CIEMAT, with an activity of $35.44 \mathrm{~Bq} / \mathrm{g}$. To do this, a known quantity of ${ }^{226} \mathrm{Ra}$ was taken, taken to a scintillation vial and diluted to a final volume of $10 \mathrm{~mL}$. Subsequently, the scintillator solution was added to the vial, and it was kept for 25 days to achieve the secular equilibrium between ${ }^{226} \mathrm{Ra}$ and ${ }^{222} \mathrm{Rn}$.

Both the determination of ${ }^{222} \mathrm{Rn}$ and that of ${ }^{226} \mathrm{Ra}$ were carried out from the direct determination of the activity of ${ }^{222} \mathrm{Rn}$ in secular equilibrium with its shortlived decay products, ${ }^{218} \mathrm{Po}$ and ${ }^{214} \mathrm{Po}$ ( $\alpha$ emitters). For the measurement of radon's activity, it was necessary to wait three hours after preparation of the vial to achieve equilibrium, while for radium's, this time amounts to approximately one month. Each sample has been measured 12 cycles of 200 minutes.

\subsection{Gamma-ray Spectrometry}

The equipment used uses a CANBERRA brand Intrinsic Germanium Detector (HPGe), reverse type, model GR-2020 $7500 \mathrm{SL}$, in vertical configuration. It has a Beryllium sheet of $50 \mathrm{~mm}$ in diameter and 0.5 $\mathrm{mm}$ thick to measure low-energy photons or X-rays. The arrangement of its electrodes is the reverse of the conventional coaxial type.

The energy calibration is carried out using a series of standard encapsulated sources with well-defined photopics and energies between $50-1900 \mathrm{KeV}$ on 7680 channels. The efficiency calibration is based on the measurement of a standard, supplied by CIEMAT.

The measurement of radon and radium will be carried out from the measurement of the activity of ${ }^{214} \mathrm{~Pb}$ and ${ }^{214} \mathrm{Bi}$, which are $\beta$ emitters and in turn emit photons at different energy ranges 295.21 KeV (19.20\%) and $351.92 \mathrm{KeV}(37.20 \%)$ for $214 \mathrm{~Pb}$; and $609.31 \mathrm{Kev}(46.30 \%), 1120.29 \mathrm{KeV}$ (15.10\%) and 1764.49 (15.80\%) for ${ }^{214} \mathrm{Bi}$ [16]. The total measurement time of each sample has been $1500 \mathrm{~min}$. For the analysis of the spectra, the software used was Genie2000 v.2.0.

\section{RESULTS AND DISCUSSION}

$$
\text { 4.1. Determination of }{ }^{226} R a \text { and }{ }^{222} R n \text {. }
$$

According to Directive 2013/51 / EURATOM of the European Council, of October 22, 2013, the permitted concentration of ${ }^{222} \mathrm{Rn}$ in drinking water is $100 \mathrm{~Bq} / \mathrm{L}$, however, each Member State may establish its own limit, without exceeding $1000 \mathrm{~Bq} / \mathrm{L}$. From Table 3 can be seen that, in all water sources studied, the Radon concentration levels are below the EURATOM limit, except for the water from source F6, whose value is higher in both techniques. However, according to Royal Decree 314/2016, Spain sets this limit at 500 $\mathrm{Bq} / \mathrm{L}$, so it would not exceed the Spanish limit value.

Comparing the Radon concentration values in water determined by both techniques used for its measurement, liquid scintillation and gamma spectrometry, it can be observed that there is no notable variation between the results obtained for the ${ }^{222} \mathrm{Rn}$ activity measurements.

Regarding the ${ }^{226} \mathrm{Ra}$ measurement, no activity above the Limit of Detection was found for any of the samples. This indicates that radon is exhaled from the bedrock and diffuses until it reaches the aquifer, but that there is no, or at least not at concentrations detectable by our equipment, a Radium contribution from the rock to the water. 
Table 3. Results obtained by LSC.

\begin{tabular}{|c|c|c|}
\hline Sample & ${ }^{22}$ Rn Activity (Bq/L) & Ra Activity (Bq/L) \\
\hline P1 & $3.42 \pm 1.44$ & $<5.44$ \\
P2 & $10.55 \pm 1.60$ & $<5.95$ \\
F1 & $27.68 \pm 2.08$ & $<7.52$ \\
F2 & $28.24 \pm 2.09$ & $<7.53$ \\
F3 & $<2.24$ & $<3.12$ \\
F4 & $62.15 \pm 2.74$ & $<9.52$ \\
F5 & $52.14 \pm 2.55$ & $<9.43$ \\
F6 & $150.50 \pm 4.03$ & $<16.18$ \\
F7 & $11.02 \pm 2.04$ & $<7.28$ \\
F8 & $16.67 \pm 1.94$ & $<7.44$ \\
F9 & $1.91 \pm 1.31$ & $<4.12$ \\
F10 & $2.44 \pm 1.29$ & $<5.22$ \\
F11 & $2.80 \pm 1.31$ & $<5.24$ \\
F12 & $4.10 \pm 1.34$ & $<5.69$ \\
F13 & $3.14 \pm 1.32$ & $<5.43$ \\
\hline
\end{tabular}

Table 4. Results obtained by Gamma-ray Spectrometry.

\begin{tabular}{|c|c|c|}
\hline Sample & ${ }^{222}$ Rn Activity $(\mathrm{Bq} / \mathrm{L})$ & 226Ra Activity (Bq/L) \\
\hline P1 & $3.33 \pm 1.50$ & $<5.82$ \\
P2 & $9.87 \pm 2.36$ & $<6.25$ \\
F1 & $28.41 \pm 3.29$ & $<7.97$ \\
F2 & $28.02 \pm 3.51$ & $<7.97$ \\
F3 & $<3.17$ & $<3.46$ \\
F4 & $60.87 \pm 5.15$ & $<9.40$ \\
F5 & $51.07 \pm 7.26$ & $<9.13$ \\
F6 & $148.98 \pm 18.58$ & $<15.97$ \\
F7 & $10.23 \pm 1.49$ & $<7.39$ \\
F8 & $16.41 \pm 2.30$ & $<7.56$ \\
F9 & $1.65 \pm 1.32$ & $<4.62$ \\
F10 & $2.65 \pm 1.67$ & $<5.66$ \\
F11 & $2.23 \pm 1.46$ & $<5.28$ \\
F12 & $3.48 \pm 1.89$ & $<5.91$ \\
F13 & $2.99 \pm 1.48$ & $<5.76$ \\
\hline
\end{tabular}

\subsection{Activity-Lithology Relationship}

Next, the relationship between Radon values found in the waters and values found in literature will be studied, taking into account the chemical nature of the bedrock and the soils that make up the aquifer. Aquifers are classified into 3 categories according to the mean concentration of ${ }^{222} \mathrm{Rn}$ found [17] (Table 5).

Table $5 .{ }^{222} \mathrm{Rn}$ activity in aquifers.

\begin{tabular}{|c|c|}
\hline Aquifer & 222 Rn Activity (Bq/L) \\
\hline Metamorphic rocks & $54-274$ \\
Detrital rocks & 15 \\
Sedimentary rocks & $<4$ \\
\hline
\end{tabular}

Regarding metamorphic rocks, the average value is between $54 \mathrm{~Bq} / \mathrm{L}$ and $274 \mathrm{~Bq} / \mathrm{L}$. The samples from the Alpujarra fall within this interval with a mean value in this type of lithology of $88 \pm 7 \mathrm{~Bq} / \mathrm{L}$. However, those on the coast are far below, with an average activity of $13 \pm$ $2 \mathrm{~Bq} / \mathrm{L}$.

With regard to the detrital areas, no water was measured in the Alpujarra. The average value is 15 $\mathrm{Bq} / \mathrm{L}$ and the ${ }^{222} \mathrm{Rn}$ measured in waters, in this type of aquifers on the coast, drops to $5 \pm 2 \mathrm{~Bq} / \mathrm{L}$.
Finally, in aquifers with carbonate rocks, the mean value of the Alpujarra samples is below $4 \mathrm{~Bq} / \mathrm{L}$ (theoretical value), with an average activity of $1.78 \pm$ $1.32 \mathrm{~Bq} / \mathrm{L}$. On the other hand, it is necessary to highlight the value of ${ }^{222} \mathrm{Rn}$ found in this type of aquifer on the coast of $10.08 \pm 1.76 \mathrm{~Bq} / \mathrm{L}$.

\section{CONCLUSIONS}

In this work, the concentration of ${ }^{222} \mathrm{Rn}$ and ${ }^{226} \mathrm{Ra}$ has been determined, in 15 untreated natural waters, distributed in the province of Granada (Spain).

The average activity concentration range for radon was from about 2 to $150 \mathrm{~Bq} / \mathrm{L}$, while for the activity for radium it was below the detection limit of the equipment for this isotope.

The values obtained in the measurements of Radon dissolved in the water samples of the Alpujarra are within the theoretical ranges of activity based on the lithology of the aquifer, found in the bibliography. Those corresponding to coastal sources are well below the theoretical ones for metamorphic and detrital areas, which could be due to the distance between the aquifer and the source. However, the results corresponding to the carbonate zones show activity levels well above the theoretical ones. This makes us suspect that the increase in the concentration of dissolved Radon is due to exogenous contributions such as phosphate fertilizers, or other substances used in agriculture, however, with the studies carried out we cannot establish a direct relationship between them, it would be necessary to expand this study.

There is no radiological risk to health, the waters studied are suitable for consumption. Only sample F6 exceeds by $50 \%$ the lower limit of ${ }^{222} \mathrm{Rn}$ established by the European Directive 2013/51 EURATOM of 100 $\mathrm{Bq} / \mathrm{L}$. However, it is far from the limit of $500 \mathrm{~Bq} / \mathrm{L}$ of Spanish legislation (Royal Decree 314/2016), which would mean immediate corrective action.

Acknowledgements: The authors wish to thank the Spanish Nuclear Safety Council (CSN), given its support to the Radiochemistry and Environmental Radiology Laboratory of the University of Granada since 1993 as a member of the laboratories of the Spanish Sparse Network for Environmental Surveillance, as well as the city council of Motril.

\section{REFERENCES}

1. Naciones Unidas. (27 de junio a 1 de julio de, 2016). A/71/46. Informe del Comité Científico de las Naciones Unidas para el Estudio de los Efectos de las Radiaciones Atómicas.

(United Nations. (27 Jun.-1 Jul. 2016). A/71/46. Report of the United Nations Scientific Committee on the Effects of Atomic Radiation.)

Retrieved from:

https://www.unscear.org/docs/GAreports/2016/A-7146 s V1604699.pdf

Retrieved on: Dec. 15, 2020

2. Radiaciones ionizantes: utilización y riesgos II, X. O. Aramburu, J. J. Bisbal, Eds., 2da ed., Barcelona, España: Edicions UPC, 1996.

(Ionizing radiation: use and risks II, X. O. Aramburu, J. J. Bisbal, Eds., 2nd ed., Barcelona, Spain: UPC Editions, 1996.) 
3. C. S. Fernández, "Análisis de la influencia in vitro de bajas dosis de radiación producidas por 222Rn sobre proliferación celular, apoptosis y respuesta a agentes citotóxicos," Doctor. tesis, Universidad de Cantabria, Departamento de Ciencias de la Tierra y Física de la Materia Condensada, Santander, España, 2002.

(C. S. Fernández, "Analysis of the in vitro influence of low radiation doses produced by $222 \mathrm{Rn}$ on cell proliferation, apoptosis and response to cytotoxic agents," Ph.D. thesis, University of Cantabria, Dept. of Earth Sciences and Physics of Condensed Matter, Santander, Spain, 2002.)

Retrieved from: http://hdl.handle.net/10803/10609

Retrieved on: Dec. 15, 2020

4. Dosis de radiación, Consejo de Seguridad Nuclear (CSN), Madrid, España, 2019.

(Radiation dose, Nuclear Safety Council (CSN), Madrid, Spain, 2019.)

Retrieved from:

https://www.csn.es/documents/10182/914805/Protecc i\%C3\%B3n\%2oradiol\%C3\%B3gica

Retrieved on: Dec. 15, 2020

5. WHO handbook on indoor radon: a public health perspective, WHO, Geneva, Switzerland, 2009.

Retrieved from:

https://apps.who.int/iris/bitstream/handle/10665/441 49/9789241547673 eng.pdf

Retrieved on: Dec. 15, 2020

6. IARC Monographs on the Evaluation of the Carcinogenic Risks to Humans: Man-made Mineral Fibres and Radon, vol. 43, IARC, Lyon, France, 1988.

Retrieved from:

https://www.ncbi.nlm.nih.gov/books/NBK316364/pdf

/Bookshelf NBK316364.pdf

Retrieved on: Dec. 15, 2020

7. D. Vienneau et al., "Effects of Radon and UV Exposure on Skin Cancer Mortality in Switzerland," Environ. Health Perspect., vol. 125, no. 6, 067009, Jun. 2017.

DOI: $10.1289 / \mathrm{EHP} 825$

PMid: 28686556

PMCid: PMC5744747

8. V. Rericha, M. Kulich, R. Rericha, D. L. Shore D. P. Sandler, "Incidence of leukemia, lymphoma, and multiple myeloma in Czech uranium miners: a casecohort study," Environ. Health Perspect., vol. 114, no. 6, pp. $818-822$, Jun. 2006.

DOI: $10.1289 / \mathrm{ehp} .8476$

PMid: 16759978

PMCid: PMC1480508

9. S. C. González, "Estudio del comportamiento del 222Rn en los procesos de recarga-descarga en acuíferos: simulación en laboratorio y aplicación a un caso real," Doctor. tesis, Universidad de Cantabria, Departamento de Ciencias Médicas y Quirúrgicas, Santander, España 2017.

(S. C. González, "Study of the behavior of $222 \mathrm{Rn}$ in aquifer recharge-discharge processes: laboratory simulation and application to a real case," Ph.D. thesis, University of Cantabria, Dept. of Medical and Surgical Sciences, Santander, Spain, 2017.)

Retrieved from:

https://repositorio.unican.es/xmlui/bitstream/handle/ 10902/13308/Tesis\%20SCG.pdf?sequence=1\&isAllowe $\mathrm{d}=\mathrm{y}$

Retrieved on: Dec. 15, 2020

10. Boletín oficial de Estado del gobierno de España. (Feb. 21, 2003). BOE-A-2003-3596. Real Decreto 14O/2003, de 7 de febrero, por el que se establecen los criterios sanitarios de la calidad del agua de consumo humano. (State official bulletin of Spain government. (Feb. 21, 2003). BOE-A-2003-3596. Royal Decree 140/2003, of February 7, which establishes the sanitary criteria for the quality of water for human consumption.

Retrieved from:

https://www.boe.es/eli/es/rd/2003/02/o7/140/con
Retrieved on: Aug. 10, 2021

11. Boletín oficial de Estado del gobierno de España. (Jul. 30, 2016). BOE-A-2016-734O. Real Decreto 314/2016, de 29 de julio, por el que se modifican el Real Decreto 140/2003, de 7 de febrero, por el que se establecen los criterios sanitarios de la calidad del agua de consumo humano, el Real Decreto 1798/2010, de 30 de diciembre, por el que se regula la explotación $y$ comercialización de aguas minerales naturales $y$ aguas de manantial envasadas para consumo humano, y el Real Decreto 1799/2010, de 30 de diciembre, por el que se regula el proceso de elaboración y comercialización de aguas preparadas envasadas para el consumo humano.

(State official bulletin of Spain government. (Jul. 30, 2016). BOE-A-2016-7340. Royal Decree 314/2016, of July 29, which modifies Royal Decree 140/2003, of February 7, which establishes the sanitary criteria for the quality of water for human consumption, Royal Decree 1798 / 2010, of December 30, which regulates the exploitation and commercialization of natural mineral waters and spring waters packaged for human consumption, and Royal Decree 1799/2010, of December 30, which regulates the process of elaboration and commercialization of prepared waters packaged for human consumption.)

Retrieved from:

https://www.boe.es/eli/es/rd/2016/07/29/314

Retrieved on: Aug. 10, 2021

12. The Council of European Union. (Oct. 22, 2013) Council Directive 2013/51/EURATOM laying down requirements for the protection of the health of the general public with regard to radioactive substances in water intended for human consumption. Retrieved from:

https://eur-lex.europa.eu/eli/dir/2013/51/oj Retrieved on: Aug. 10, 2021

13. A. C. García, "Factores condicionantes de la radiactividad medioambiental en áreas del S.E. peninsular," Doctor. tesis, Universidad de Granada, Departamento de Química Inorgánica, Granada, España, 2000.

(A. C. García, "Conditioning factors of environmental radioactivity in areas of the peninsula," Ph.D. thesis, University of Granada, Dept. of Inorganic Chemistry, Granada, Spain, 200o.)

Retrieved from:

https://digibug.ugr.es/handle/10481/28637

Retrieved on: Jan. 20, 2021

14. A. Milena-Pérez et al., "Uranium content and uranium isotopic disequilibria as a tool to identify hydrogeochemical processes," J. Environ. Radioact., vol. 227, 106503, Feb. 2021.

DOI: $10.1016 /$ j.jenvrad.2020.106503

PMid: 33296862

15. P. B. Hahn, S. H. Pia, Determination of Radon in Drinking Water by Liquid Scintillation Counting, EPA Method 913.o, U.S. Enviromental Protection Agency (EPA), Las Vegas (NV), USA, 1991

16. S. Y. F. Chu, L. P. Ekström, R. B. Firestone, The Lund/LBNL Nuclear Data Search: Nuclide Search, LBNL, Berkeley (CA), USA, 1999.

Retrieved from:

http://nucleardata.nuclear.lu.se/toi/nucSearch.asp Retrieved on: Jan. 20, 2021

17. J. Michael, "Relationship of Radium and Radon with Geological Formations," in Radon, Radium and Uranium in Drinking Water, C. R. Cothern, P. A. Rebers, Eds., 1st ed., Chelsea (MI), USA: Lewis Publishers, 1990 , ch. 7 , pp. $83-95$.

Retrieved from: http://library.lol/main/2AC433245734EA9F96855448A 0214417A

Retrieved on: Feb. 12, 2021 